\title{
Analysis of Main Components Status of Food Security at Village/Sub-District Level in Yogyakarta Special Region
}

\author{
Suparna \\ Badan Pusat Statistik Provinsi D.I. Yogyakarta, suparna@bps.go.id
}

doi: https://doi.org/10.15642/mantik.2020.6.1.30-37

\begin{abstract}
Abstrak: Pangan merupakan aspek pokok dari kebutuhan hidup manusia untuk menjamin keberlangsungan hidup individu maupun komunitas. Perwujudan ketahanan pangan nasional dimulai dari pemenuhan pangan di wilayah terkecil yaitu desa/kelurahan. Tujuan dari analisis dengan metode komponen utama ini adalah (1) mendeskripsikan komponen utama status ketahanan pangan pada tingkat desa/kelurahan; (2) mengelompokkan desa/kelurahan berdasarkan status ketahanan pangan di Daerah Istimewa Yogyakarta. Sumber data berasal dari data sekunder (Podes 2018). Dari analisis dihasilkan beberapa hal yakni: (1) komponen utama status ketahanan pangan pada tingkat desa/kelurahan di Daerah Istimewa Yogyakarta ada lima, yaitu keterjangkauan wilayah/akses, ketersediaan pangan, kesehatan lingkungan, jaminan akses, dan pemanfaatan pangan; (2) tipologi desa/kelurahan berdasarkan status ketahanan pangan di Daerah Istimewa Yogyakarta ada 4 yakni: (a) rawan pangan meliputi 55 desa/kelurahan (b) kurang tahan meliputi 169 desa/keluarahan; (c) tipologi 3 rentan tahan meliputi 170 desa; (d) tipologi 4 tahan pangan meliputi 44 desa.
\end{abstract}

Kata kunci: Komponen utama; Ketahanan pangan; Daerah Istimewa Yogyakarta; Desa

\begin{abstract}
Food is a basic aspect of the needs of human life to ensure the survival of individuals and communities. The realization of national food security starts from the fulfillment of food in the smallest region, namely the village /sub-districts. The objectives of the analysis using the principal component method are (1) to describe the main components of the status of food security at the village/sub-districts level; (2) to grouping villages/sub-districts based on food security status in the Yogyakarta Special Region. The data source of analysis comes from secondary data (Podes 2018). From the analysis produced several things, namely: (1) the main components of the status of food security at the village/sub-district level in the Yogyakarta Special Region there are five, namely affordability/access, food availability, environmental health, guaranteed access, and utilization of food; (2) village/sub-districts typology based on the status of food security in the Yogyakarta Special Region, namely 4: (a) food insecurity covering 55 villages/sub-districts (b) less resistant to 169 villages/sub-districts; (c) typologies 3 are vulnerable to cover 170 villages/sub-districts; (d) foodresistant typology covering 44 villages/sub-districts.
\end{abstract}

Keywords: Principal component; Food security, Yogyakarta Special Region; Village 


\section{Introduction}

Food insecurity is still a global issue which is the main concern to date, not only in poor and developing countries but also in developed countries [1][2][3]. The importance of the problem of food insecurity is the main point discussed at the world level meeting set forth in the Sustainable Development Goals (SDG's). In developing countries, more than half of household income is used to meet their food needs and this causes a precarious situation if there are sudden price fluctuations that can push people into poverty and impede poverty alleviation efforts [4][5].

The Food and Agriculture Organization estimates that 1.5 billion people in the world are affected by one or more forms of micronutrient deficiency[6]. Iron deficiency in women of reproductive age is a form of micronutrient deficiency that can occur also in women who are overweight or well cared for. The high prevalence of each form of deficiency or malnutrition in the form of short children is found in 73 countries; lean children in 14 countries; overweight children in 29 countries; adult obesity in 101 countries; and anemia in women of reproductive age in 35 countries. The prevalence threshold that is considered high for short children is 20 percent or more; for thin children and overweight children, the threshold is 10 percent or more. Indonesia is the only country that shows a high prevalence of these three forms of child malnutrition.

Yogyakarta Special Region is the province with the highest percentage of poor population in Java, which is still 11.81 percent and still relies on the agricultural sector as the main axis of its economy. This is evident from the contribution of the agricultural sector in the order of the four major regional gross domestic product (GRDP) and the proportion reached 9.78 percent in 2018 [7]. Bearing in mind that food security as a human right and limited food production greatly affect the achievement of food security at the community level, it is necessary to further study food security at the village /sub-district level in order to give birth to efforts in achieving village/sub-district to become food self-sufficient.

The embodiment of national food security starts from the fulfillment of food in the smallest region, namely villages as the basis of agricultural activities [8]. In addition, the village is also an entry point for the entry of various programs that support the realization of food security at the household level which cumulatively supports the realization of food security at the district /city, provincial, and national levels. Food security is multidimensional, both in terms of supply and utilization, and regional levels [9][10][11]. There are many variables that explain the number, so we need indicators that explain the main dimensions of food security. The method used is mostly in the form of principal component analysis [12][13][14].

\section{Methods}

\subsection{Variable and Component Analysis}

Achieving food security is a guarantee against the threat of hunger and malnutrition, both of which can slow down economic development [15][16]. Thus poverty and food security are interrelated [17]. Food system resilience is basically to ensure adequate and access to food for everyone. Sufficiency that is meant is sufficiency in quantity and quality with access including economic and physical access [18][19]. There are three main dimensions of food security delivered by the Food Agricultural Organization (FAO), namely the availability, access and utilization of food.

Principal component analysis is a statistical analysis tool that aims to reduce the dimensions of the data by generating new variables (main components) which are linear combinations of the original variables so that the main component variances are maximum and the main components are mutually independent [20]. The principal component analysis model can be written with the following matrix. 


$$
\left[\begin{array}{c}
Y_{1} \\
Y_{\ldots} \\
Y_{m}
\end{array}\right]=\left[\begin{array}{ccc}
a_{11} & a_{1 . .} & a_{1 p} \\
a_{1 \ldots} & a_{\ldots} & a_{\ldots p} \\
a_{m 1} & a_{m \ldots} & a_{m p}
\end{array}\right]\left[\begin{array}{l}
X_{1} \\
X_{\ldots} \\
X_{p}
\end{array}\right]
$$

In equation (1):

$\mathrm{Y}_{1}=$ the first major component, the component that has the largest variance

$\mathrm{Y} .$. = the second main component and so on, the component that has the second largest variance and so on

$\mathrm{Y}_{\mathrm{m}}=$ the $\mathrm{m}$-th main component, the component that has the $\mathrm{m}$-th largest variance

$\mathrm{X}_{1}=$ first origin variable

$X_{\text {.. }}=$ second origin variable and so on

$\mathrm{X}_{\mathrm{p}}=\mathrm{p}$-origin variable

$\mathrm{m}=$ number of main components

$\mathrm{p} \quad=$ number of original variables.

The main components do not correlate and have the same variation with the root characteristic of $\Sigma$. The root characteristic of the diversity matrix $\Sigma$ is a variant of the main component $\mathrm{Y}$, so the diversity matrix of $\mathrm{Y}$ is:

$$
\Sigma=\left[\begin{array}{ccc}
\lambda_{1} & 0 & 0 \\
0 & \lambda_{\ldots} & 0 \\
0 & 0 & \lambda_{p}
\end{array}\right]
$$

The total diversity of origin variables will be the same as the total diversity explained by the main components, namely:

$$
\sum_{i=1}^{p} \operatorname{var}\left(X_{i)}=\lambda_{1}+\lambda_{\ldots}+\lambda_{p}=\sum_{i=1}^{m} \operatorname{var}\left(Y_{i}\right)\right.
$$

Depreciation of the dimensions of the original variables is done by taking a small number of components that are able to explain the largest part of the diversity of data. If the main component is taken as many as q component, where $\mathrm{q}<\mathrm{p}$, then the proportion of total diversity that can be explained by the $\mathrm{i}$-th major component is:

with $\mathrm{i}=1,2, \ldots, \mathrm{p}$

$$
\frac{\lambda_{i}}{\lambda_{1}+\lambda_{2}+\cdots+\lambda_{p}}
$$

If the variable units covered are not the same, it is necessary to standardize before the principal component analysis is performed. Due to the standardization of this data, the covariance matrix variance of the standardized data will be the same as the data correlation matrix before it is standardized and the magnitude of the total variance of the main components is equal to the number of origin variables (p). The number of main components (m) can be determined by various criteria, one of the criteria commonly used is to use the criterion of the magnitude of the main component variance.

\subsection{Research methods}

The method used in this study is the analysis of the main components using food security indicators that refer to the variables in the classification used in making Food Security and Vulnerability Atlas (FSVA) maps in 2009 and 2015. Typologies are formed based on the results of the main component scores, which will show the food security status of a village/kelurahan. 
Broadly speaking, the stages in analyzing the principal components are as follows:

a. Determine what variables are eligible for further analysis. Through the information obtained based on the 2018 Podes data collection, the variables considered relevant are:

$\mathrm{X} 1=$ The ratio of food stalls $/$ food stalls per 1.000 households

$\mathrm{X} 2=$ ratio of shops $/$ grocery stalls per 1.000 households

$\mathrm{X} 3=$ Percentage of agricultural land to total village/sub-district area

$\mathrm{X} 4=$ Percentage of population receiving Jamkesmas (PBI)

$\mathrm{X} 5=$ SKTM ratio (certificate of incapacity) per 1.000 population

X6 $=$ Percentage of poor households (heads of households) according to the village head/lurah

X7 $=$ Non-electricity consumption ratio per 10.000 families

$\mathrm{X} 8=$ Index of access of village main roads is inadequate

$\mathrm{X} 9=$ Distance of village/village office to nearest main sub-district office

$\mathrm{X} 10=$ Index of drinking and bathing/washing water sources

$\mathrm{X} 11=$ Index of final disposal of feces and liquid waste

$\mathrm{X} 12=$ Ratio of health workers per 10.000 population

$\mathrm{X} 13=$ Ratio of malnutrition residents per 10.000 population

$\mathrm{X} 14=$ Active posyandu (integrated healthcare centre) ratio per 10.000 population

$\mathrm{X} 15=$ Ratio of slums to 10.000 families

b. Calculate the correlation with the Bartlett test of spericity and MSA (measure of sampling) measurements.

c. Extraction. The component extraction method used in this study is the PCA (Principal Component Analysis) method. Determination of the number of components is based on the amount of eigen value of each component that appears. Eigen value is the number of variants explained by each component.

\section{Result and Discussion}

\subsection{Test of data assumptions}

Kaiser-Meyer-Olkin (KMO) of data adequacy test is conducted to determine whether the data to be used meets the requirements for component analysis or not, while the Bartlett test shows whether there is correlation between variables. Measure of Sampling Adequacy (MSA) is also used to determine whether the variables are sufficient for further analysis.

Based on the test results obtained a KMO value of 0,744 or it can be said that the data is sufficient for further analysis (greater than 0.5). The results of the Bartlett test are also significant, with a p-value smaller than the significance level $(\alpha)$ of 0,05 , which means that there are correlations between variables. The results of the Measure of Sampling Adequacy (MSA) can be seen from the value of the anti-image correlation matrix. If the MSA value is greater than 0,5 then the variable is sufficient for further analysis. If there is an MSA value of initial variables less than 0,5 must be excluded one by one from the analysis, sorted from the variable whose MSA value is the smallest and not used again in subsequent analyzes.

\subsection{Principal Component Analysis Result}

By using the principal component analysis method, the communality value is obtained. The value of communalities formed shows how much diversity of variables can be explained by the components formed.

Based on the extraction value obtained from the results of the analysis of the main components shows that for the variable X1 = ratio of stalls/ food stalls per 1.000 households by 70,4 percent the diversity of these variables can be explained by the components formed, 
while for the diversity of the variable $\mathrm{X} 2=$ ratio of shops/ grocery stalls per 1.000 households can be explained by the components formed by 76,1 percent. Diversity X3 = Percentage of agricultural land to total village/ sub-district area explained by the component formed by 55,2 percent, and so on up to 64,0 percent diversity X14 $=$ The ratio of active posyandu per 10.000 population is explained by the component formed. Finally, for diversity $\mathrm{X} 15=$ The ratio of slum families per 10.000 families is explained by the component formed by 42,6 percent.

Furthermore, it can be seen how many components are formed based on eigenvalues (eigenvalues). Components which are stated to represent other variables are components that have an eigenvalue of more than 1 (one). The results of the eigenvalues of each component are listed in Table 1.

Based on Table 1. It can be seen that more than one eigenvalue there are 5 components. The first component has an eigenvalue of 2,935 and component five has an eigenvalue of 1,004 . Of the thirteen variables can be reduced and formed into five components in which the five components are able to explain 56,56 percent of total diversity.

Table 1. Eigenvalues of each component

\begin{tabular}{lrrr}
\hline & \multicolumn{3}{l}{ Total Variance Explained } \\
\hline \multirow{3}{*}{ Component } & \multicolumn{3}{c}{ Eigen values } \\
\cline { 2 - 4 } & Total & \% of Variance & Cumulative \% \\
\hline 1 & 2,935 & 22,575 & 22,575 \\
\hline 2 & 1,295 & 9,965 & 32,540 \\
\hline 3 & 1,095 & 8,424 & 40,964 \\
\hline 4 & 1,024 & 7,875 & 48,839 \\
\hline 5 & 1,004 & 7,722 & 56,561 \\
\hline \multicolumn{4}{l}{ Extraction Method: Principal Component Analysis. }
\end{tabular}

For component 1 which can explain the greatest variance can be perceived as a component of regional affordability / access, while in component 2 it can be described as food availability. Component 3 can be called environmental health, component 4 is called guaranteed access, and component 5 is food use.

This is formed based on the largest correlation of each variable to the existing components based on Rotated Components that are also obtained. The results of the analysis of the main components show that the high correlation variable with component 1 , namely X3 $=$ Percentage of agricultural land to the total area of the village/sub-district has a correlation of 0,$608 ; \mathrm{X} 6=$ Percentage of poor households according to the village / lurah head who has a correlation of 0,$662 ; \mathrm{X} 8=$ Inadequate access road index for the main village has a correlation of 0,638 ; and $\mathrm{X} 9=$ Distance of the village/village office to the nearest main sub-district office has a correlation of 0,607 . High variable correlation with component 2 , namely $\mathrm{X} 1=$ ratio of stalls $/$ food stalls per 1.000 households has a correlation of 0,$736 ; \mathrm{X} 2=$ ratio of shops / grocery stalls per 1.000 households and X12 = Ratio of health workers per 10.000 residents, each of which has a correlation of 0,860 and 0,430 . Likewise, component 3 consists of variables X11 = index of final disposal of sewage and liquid waste and X14 = ratio of active posyandu per 10.000 population. Component 4 consists of X5 = SKTM ratio per 1.000 inhabitants and X10 = Index of drinking and bathing / washing water sources, while component 5 consists of $\mathrm{X} 7=$ ratio of non-electricity users per 10.000 families and X15 = ratio of slum families per 10.000 families.

\subsection{Village/Sub-district Typology}

The objects that are grouped are villages /sub-district throughout the Yogyakarta Special Region using information on the results of the analysis of the main components. 
Village /sub-district grouping is done based on food security index which is the sum of scores of all main components with the same weight.

The grouping process uses statistical considerations with group limits in the form of an average plus minus one standard deviation. The number of groups obtained was four groups. This is with consideration of the number of aspects of food security, amounting to four (food resistant, susceptible resistant, less resistant, and food insecurity). Food resistance if the combined component score is more than the average plus one standard deviation, vulnerable to hold if the score is between the average added one standard deviation, less food resistance if the score is between the average minus one standard deviation, and food insecurity if the score smaller than the average minus one standard deviation.

Based on table 2 it can be shown that there are 55 villages/sub-district in the Special Region of Yogyakarta $(12,6 \%)$ which can be called a food insecure area. Meanwhile, there are 44 regions $(10 \%)$ of truly food-resistant villages/sub-district, while $39 \%$ of foodresistant and vulnerable villages /sub-district are vulnerable. If we pay attention per district/city, villages/sub-district that are food insecure, especially in Gunungkidul Regency, have 22 villages. Then followed in Bantul Regency as many as 17 villages and in the City of Yogyakarta as many as 14 subdistricts. For villages/sub-district that are categorized as food resistant, mainly in the Regencies of Gunungkidul, Kulonprogo and Sleman.

Table 2. Typology of villages/sub-district based on food security status in Yogyakarta Special Region, 2018

\begin{tabular}{|c|c|c|c|c|c|c|c|}
\hline \multirow{2}{*}{\multicolumn{3}{|c|}{ Regency/city }} & \multicolumn{4}{|c|}{ Typology } & \multirow{3}{*}{$\begin{array}{r}\text { Total } \\
\\
88\end{array}$} \\
\hline & & & \multirow{2}{*}{$\begin{array}{r}\begin{array}{c}\text { Food } \\
\text { insecurity }\end{array} \\
2\end{array}$} & \multirow{2}{*}{\begin{tabular}{r}
\multicolumn{1}{c}{ Less } \\
resistant
\end{tabular}} & \multirow{2}{*}{$\begin{array}{r}\begin{array}{c}\text { Susceptible } \\
\text { resistant }\end{array} \\
39\end{array}$} & \multirow{2}{*}{\begin{tabular}{r}
\multicolumn{1}{c}{$\begin{array}{c}\text { Food } \\
\text { resistant }\end{array}$} \\
10
\end{tabular}} & \\
\hline 01 & Kulonprogo & $\mathrm{N}$ & & & & & \\
\hline & & $\%$ & $2,3 \%$ & $42,0 \%$ & $44,3 \%$ & $11,4 \%$ & $100,0 \%$ \\
\hline \multirow[t]{2}{*}{02} & Bantul & $\mathrm{N}$ & 17 & 41 & 16 & 1 & 75 \\
\hline & & $\%$ & $22,7 \%$ & $54,7 \%$ & $21,3 \%$ & $1,3 \%$ & $100,0 \%$ \\
\hline \multirow[t]{2}{*}{03} & Gunungkidul & $\mathrm{N}$ & 22 & 53 & 49 & 20 & 144 \\
\hline & & $\%$ & $15,3 \%$ & $36,8 \%$ & $34,0 \%$ & $13,9 \%$ & $100,0 \%$ \\
\hline \multirow[t]{2}{*}{04} & Sleman & $\mathrm{N}$ & 0 & 19 & 57 & 10 & 86 \\
\hline & & $\%$ & $0,0 \%$ & $22,1 \%$ & $66,3 \%$ & $11,6 \%$ & $100,0 \%$ \\
\hline \multirow[t]{2}{*}{71} & Yogyakarta & $\mathrm{N}$ & 14 & 19 & 9 & 3 & 45 \\
\hline & & $\%$ & $31,1 \%$ & $42,2 \%$ & $20,0 \%$ & $6,7 \%$ & $100,0 \%$ \\
\hline \multirow[t]{2}{*}{34} & D.I. Yogyakarta & $\mathrm{N}$ & 55 & 169 & 170 & 44 & 438 \\
\hline & & $\%$ & $12,6 \%$ & $38,6 \%$ & $38,8 \%$ & $10,0 \%$ & $100,0 \%$ \\
\hline
\end{tabular}

\section{Conclusions}

Based on the results of the analysis that has been done there are several things that can be concluded, namely:

a. Analysis of the main components reduces from thirteen initial variables to five new components. Component one describes area / access affordability, while component 2 can be described as food availability. Component 3 can be called environmental health, component 4 is called guaranteed access, and component 5 is food use.

b. The results of the typology of villages/ wards in the Yogyakarta Special Region get 55 villages/ sub-district in the Yogyakarta Special Region $(12,6 \%)$ can be called a food insecure area. Meanwhile, there are 44 regions (10\%) of truly food-resistant villages/sub-district, while $39 \%$ of food-resistant and vulnerable villages/sub-district are vulnerable. If we pay attention per district/ city, villages/sub-district that are food insecure, especially in Gunungkidul Regency, have 22 villages. Then followed in 
Bantul Regency as many as 17 villages and in the City of Yogyakarta as many as 14 villages. For villages/kelurahan that are categorized as food resistant, mainly in the Regencies of Gunungkidul, Kulonprogo and Sleman.

There are several things that can be suggested, namely:

a. To increase the affordability of the area/access, it is necessary to optimize the existing irrigation channels or build irrigation channels in order to increase the area of irrigated land which in the end will increase the productivity of agricultural land. Efforts are needed to reduce or even prevent the conversion of productive agricultural lands. As well as providing production incentives for farmers to have the motivation to continue producing. Need better and serious attention to empowerment programs and increasing community income through comprehensive programs involving all relevant regional apparatus organizations.

b. To increase food availability, it is necessary to increase the number of shops/grocery stalls and food stalls/food stalls so that people can easily access food. Utilization of cooperatives or the establishment of shops as food providers so that they can reach all regions of Yogyakarta Special Region.

\section{References}

[1] P. Conceição, S. Levine, M. Lipton, and A. Warren-Rodríguez, "Toward a food secure future: Ensuring food security for sustainable human development in SubSaharan Africa," Food Policy, vol. 60, pp. 1-9, 2016, doi: 10.1016/j.foodpol.2016.02.003.

[2] B. Häsler et al., "Using participatory rural appraisal to investigate food production, nutrition and safety in the Tanzanian dairy value chain," Glob. Food Sec., vol. 20, no. September 2018, pp. 122-131, 2019, doi: 10.1016/j.gfs.2019.01.006.

[3] Trussell Trust, "The State of Hunger: Introduction to a Study of Poverty and Food Insecurity in the UK," no. November, pp. 1-32, 2019.

[4] A. Ickowitz, B. Powell, D. Rowland, A. Jones, and T. Sunderland, "Agricultural intensification, dietary diversity, and markets in the global food security narrative," Glob. Food Sec., vol. 20, no. November 2018, pp. 9-16, 2019, doi: 10.1016/j.gfs.2018.11.002.

[5] P. V Preckel and T. W. Hertel, "Poverty Analysis Using an International CrossCountry Demand System," 2007.

[6] FAO, IFAD, UNICEF, WFP, and WHO, Food Security and Nutrition in the World the State of Building Climate Resilience for Food Security and Nutrition. 2018.

[7] BPS D.I. Yogyakarta, "Daerah Istimewa Yogyakarta Dalam Angka 2018," p. 464, 2018.

[8] K. Nainggolan,"Program akselerasi pemantapan ketahanan pangan berbasis pedesaan. 2006, [Online]. Available: http://pse.litbang_deptan.go.id/pdffiles/pros_kaman_06.pdf.

[9] A. Suryana, "Menuju Ketahanan Pangan Indonesia Berkelanjutan 2025: Tantangan dan Penanganannya," Forum Penelit. Agro Ekon., vol. 32, no. 2, p. 123, 2014, doi: 10.21082/fae.v32n2.2014.123-135.

[10] K. Thome, M. D. Smith, K. Daugherty, N. Rada, C. Christensen, and B. Meade, "International Food Security, 2019-2029," no. GFA-30, p. 65, 2019, [Online]. Available: www.ers.usda.gov.

[11] C. Béné et al., "Understanding food systems drivers: A critical review of the literature," Glob. Food Sec., vol. 23, no. April, pp. 149-159, 2019, doi: 10.1016/j.gfs.2019.04.009.

[12] A. Shrestha, R. P. Koju, S. A. A. Beresford, K. C. G. Chan, B. M. Karmacharya, and A. L. Fitzpatrick, "Food patterns measured by principal component analysis and obesity in the Nepalese adult," Heart Asia, vol. 8, no. 1, pp. 46-53, 2016, doi: 
10.1136/heartasia-2015-010666.

[13] M. Šnirc, M. Kral, M. Ošt’ádalová, J. Golian, and B. Tremlová, “Application of principal component analysis method for characterization chemical, technological, and textural parameters of farmed and pastured red deer," Int. J. Food Prop., vol. 20, no. 4, pp. 754-761, 2017, doi: 10.1080/10942912.2016.1180532.

[14] M. G. Thorpe, C. M. Milte, D. Crawford, and S. A. McNaughton, "A comparison of the dietary patterns derived by principal component analysis and cluster analysis in older Australians," Int. J. Behav. Nutr. Phys. Act., vol. 13, no. 1, pp. 1-14, 2016, doi: 10.1186/s12966-016-0353-2.

[15] A. Davies, "Food security initiatives in Nigeria: prospects and challenges.," $J$. Sustain. Dev. Africa, vol. 11, no. 1, pp. 186-202, 2009, [Online]. Available: http://www.cabdirect.org/abstracts/20103307624.html.

[16] S. C. Omar, "Ensuring food security during the Covid-19 pandemic," no. April, 2020.

[17] OECD, "Agriculture: Achieving greater food security," March, 2015.

[18] D. M. Tendall et al., "Food system resilience: Defining the concept," Glob. Food Sec., vol. 6, pp. 17-23, 2015, doi: 10.1016/j.gfs.2015.08.001.

[19] W. A. and M. H. Amjad A.H., Maqbool H.S., "Assessing Food Insecurity Trends and Determinants by using Mix Methods in Pakistan: Evidence from Household Pooled Data (2005- 2014)," Sarhad J. Agric., vol. 35, no. I, pp. 87-101, 2019, doi: http://dx.doi.org/10.17582/journal.sja/2019/35.1.87.101.

[20] W. Härdle and L. Simar, "Applied Multivariate Statistical Analysis," Appl. Multivar. Stat. Anal., no. April, 2003, doi: 10.1007/978-3-662-05802-2. 